\title{
Gentamicin pharmacokinetics and pharmacodynamic correlation in pediatrics-A systematic review
}

\author{
Keerthana Chandrasekar, Vahini B, Vijay V, Shalini R, Arun KP* \\ Department of Pharmacy Practice, JSS College of Pharmacy, JSS Academy of Higher Education \& Research, Ooty, Nilgiris, Tamil Nadu, India.
}

\author{
ARTICLE INFO \\ Received on: 28/06/2021 \\ Accepted on: 17/09/2021 \\ Available online: 03/11/2021
Key words:
Gentamicin, population
pharmacokinetics,
pharmacokinetics and
pharmacodynamics
correlation, nonlinear mixed
effects modeling (NONMEM),
therapeutic drug monitoring
(TDM), antibiotic sensitivity
test (AST).

\begin{abstract}
The primary objective of the review is to correlate the pharmacokinetics and pharmacodynamics data of gentamicin. A thorough literature search was carried out using the databases such as Scopus, PubMed, Google Scholar, and Cochrane. The different types of study designs included were observational (5), prospective (7), retrospective (9), cross-sectional (2), retrospective cross-sectional (1), and retrospective cohort (1). The data were extracted from these studies and it was reviewed by the authors. A total of 149 studies were identified through the database; after removing duplicates, 100 articles were screened, 31 articles were excluded from screening, and 69 articles were included. Out of 69 articles, 26 full-text articles were included and 43 full-text articles were excluded. The dosage recommendations under different disease conditions and their minimum inhibitory concentrations were reviewed. For sepsis condition, $5 \mathrm{mg} / \mathrm{kg} /$ day is the ideal dose of gentamicin and $>2 \mathrm{mg} / \mathrm{l}$ shows minimum inhibitory concentration; for urinary tract infection, $4.5-7.5 \mathrm{mg} / \mathrm{kg} /$ day dose of gentamicin shows a minimum inhibitory concentration of $>2 \mathrm{mg} / 1$ toward organism. For severe malnutrition, $7.5 \mathrm{mg} / \mathrm{kg} /$ day dose of gentamicin showed an inhibitory concentration of $>2 \mathrm{mg} / \mathrm{l}$. Pharmacokinetic and pharmacodynamic correlation model helps to identify the concentration of gentamicin showing sensitivity and resistance toward organisms at a targeted dosage range.
\end{abstract}

\section{INTRODUCTION}

When there is a seasonal change, the prevalence of respiratory infections is high in children. Gentamicin is a narrow therapeutic index drug belonging to the class of aminoglycosides which is effective against Gram-negative organisms such as Escherichia coli, Klebsiella species, Pseudomonas aeruginosa, Klebsiella pneumonia, and Staphylococcus aureus, and resistant against Enterobacteriaceae, Enterococci, and Staphylococci (Krause et al., 2016; Lundergan et al., 1999; MacDougall and Chambers, 2011). It is mainly indicated for the treatment of both upper and lower respiratory tract infections, urinary tract infections (UTI), meningitis, bacterial neonatal sepsis, peritonitis, bacterial septicemia, skin, bone, and soft tissue infections

"Corresponding Author

K. P. Arun, Department of Pharmacy Practice, JSS College of Pharmacy, JSS Academy of Higher Education \& Research, Ooty, Nilgiris, Tamil Nadu, India.E-mail: kparun@jssuni.edu.in
(Pacifici, 2015). The mechanism action of gentamicin involves the inhibition of protein synthesis of bacteria by binding with $30 \mathrm{~S}$ ribosomal subunits, causing the misreading of the mRNA, and facilitating the premature termination of translation (Hahn and Sarre, 1969; Kushner et al., 2016). The available dosage forms of gentamicin are ointment, injections, and drops (Bloomfield et al., 1978). The preferable route of gentamicin administration includes topical routes, intramuscular (IM), intravenous (IV), intrathecal, auricular, and ophthalmic drops (Bloomfield et al., 1978; Haddad et al., 1986). The recommended dose of gentamicin in pediatrics is $2-7.5 \mathrm{mg} / \mathrm{kg}$ every 8 hours; with an initial dose of $2-5 \mathrm{mg} / \mathrm{kg} / \mathrm{day}$ and the maximum dose is $7.5 \mathrm{mg} / \mathrm{kg} / \mathrm{day}$. During maintenance dose therapy, dose adjustment may be required for renal failure patients (Taylor and Keane, 1976). The main adverse effects of gentamicin include nephrotoxicity and ototoxicity, wherein nephrotoxicity is reversible and ototoxicity is irreversible (Saleh et al., 2016). Gentamicin is contraindicated in myasthenia gravis, where neuromuscular transmission may be impaired (Garraghan and Fallon, 2015). Gentamicin interacts 
with penicillin or cephalosporin, cyclosporin, amphotericin B, and furosemide (Garraghan and Fallon, 2015; Noone and Pattison, 1971). Pharmacokinetic parameters of gentamicin include absorption: poorly absorbed orally; volume of distribution $\left(V_{\mathrm{d}}\right)$ in infants $(0.4 \pm 0.1 \mathrm{1} / \mathrm{kg})$, neonates $(0.45 \pm 0.1 \mathrm{l} /$ $\mathrm{kg})$, and children $(0.35 \pm 0.15 \mathrm{l} / \mathrm{kg})$; protein binding $(0 \%-30 \%)$; half-life in neonates: if $<1$ week for $3-11.5$ hours, 1 week to 1 month for 3-6 hour, infants $4 \pm 1$ hour, children $2 \pm 1$ hour, peak serum concentration for IM route within 30-90 minutes; and IV route within 30 minutes, which is excreted through the kidneys (Nocton and Gedeit, 2018). Gentamicin has an average trough concentration of $<2 \mu \mathrm{g} / \mathrm{ml}$ and an average peak concentration of $<12 \mu \mathrm{g} / \mathrm{ml}$ (Garraghan and Fallon, 2015).

Nowadays, all antibiotics are susceptible to bacteria which lead to irrational use of antibiotics. Antibiotic sensitivity testing (AST) being a scientific tool will be helpful to identify the bacteria and will be helpful in rationalizing the antibiotic treatment.

AST is a test that determines the sensitivity of bacteria to an antibiotic. The two methods of AST are dilution method (broth dilution and agar dilution method) and diffusion method (Stokes' disk diffusion and Kirby-Bauer disk diffusion method).

The dilution method is used to find out the growth and identification of bacterial populations. Micro-dilution and macro-dilution are the two types of dilutions, wherein broth and agar are the commonly used media. In broth dilution, consecutive twofold dilutions $(1,2,4,8$, and $12 \mu \mathrm{l})$ of antibiotics are made and in agar dilutions and antibiotics are diluted in agar medium (Khan et al., 2019). The disk diffusion method is the gold standard for confirming the susceptibility of bacteria. In this method, an isolated bacteria colony is selected, suspended into growth media, and standardized through a turbidity test (Graham et al., 1985).

Pharmacokinetics refers to the study of the time course of drug absorption, distribution, metabolism, and excretion. Pharmacodynamics refers to the relationship between drug concentration at the site of action and their effect (Tozer and Rowland, 2006).

The pharmacokinetic-pharmacodynamic modeling links the pharmacokinetics and pharmacodynamics to evaluate doseconcentration-response relationships and describe the effect of time courses resulting from a drug dose (Meibohm and Derendorf, 1997). Hence, this review focuses on the pharmacokineticpharmacodynamics modeling of gentamicin in pediatrics.

The objective of the study is to correlate pharmacokinetic and pharmacodynamic data of gentamicin for the pediatric population for different disease conditions.

\section{MATERIALS AND METHODS}

\section{Types of participants}

It includes pharmacokinetics, pharmacodynamics (sensitivity), and Pharmacokinetic- Pharmacodynamic (PK-PD) correlation of gentamicin studies that were carried out in the pediatric population for different disease conditions.

\section{Types of interventions and outcome}

Intervention - comparison of pharmacokinetic and pharmacodynamic data of gentamicin. Outcome - to understand the concentration profile of gentamicin showing sensitivity against bacterial infections.

\section{SEARCH METHODS}

\section{Electronic searches}

A thorough literature search was conducted from the year 1998 to 2020, using the keywords aminoglycosides, gentamicin, population pharmacokinetics, pediatrics, pharmacokinetics and pharmacodynamics correlation, nonlinear mixed effects modeling, therapeutic drug monitoring, and antibiotic sensitivity test in the following database: Cochrane Library, PubMed, Scopus, and Google Scholar.

\section{Data collection and analysis}

The collected data was analyzed based on the inclusion and exclusion criteria. The pharmacokinetics and pharmacodynamics studies were categorized, followed by a comparison of the pharmacokinetic and pharmacodynamic profiles of gentamicin.

\section{Data extraction and analysis}

Three authors independently extracted all the studies. The following study characteristics were collected: author, study design, country of publication, age range of participants, year of publication, and dose and indication for gentamicin.

A total of 149 articles were identified through searching. 100 articles were screened after removing duplication; 31 articles were excluded from screening; and 69 articles were included. Out of 69 articles, 26 articles were included in the study and 43 articles were excluded. The Preferred Reporting Items for Systematic Reviews and Meta- Analyses (PRISMA) flow diagram describes the study as shown in Figure 1. All articles included in the review were conducted in pediatrics.

\section{RESULTS AND DISCUSSION}

\section{Pharmacokinetic approach in different disease conditions}

In Gram-negative bacterial infections, pediatric patients receiving a dose of $7.5 \mathrm{mg} / \mathrm{kg} /$ day of gentamicin as the drug of choice. Plasma samples were checked for the targeted trough concentration $<2 \mu \mathrm{g} / \mathrm{ml}$ and peak concentration $<10 \mu \mathrm{g} / \mathrm{ml}$. The concentration was found to exceed the therapeutic range. The dose was adjusted to $3 \mathrm{mg} / \mathrm{kg} / \mathrm{day}$; their trough and peak concentrations were found to be $1-2 \mu \mathrm{g} / \mathrm{ml}$ and $6 \mu \mathrm{g} / \mathrm{ml}$, respectively. The adjusted daily dose of gentamicin was $3-5 \mathrm{mg} / \mathrm{kg}$ /day which were found to be ideal for Gram-negative bacterial infections (Ismail et al., 1990).

For sepsis, meningitis, and neutropenic fever, neonates received a dose of $5 \mathrm{mg} / \mathrm{kg} /$ day of gentamicin every 24 hours as the drug of choice. Blood samples were collected to check for the targeted peak concentration of $8-10 \mathrm{mg} / \mathrm{l}$ and trough concentration $<2 \mathrm{mg} / \mathrm{l}$. The first dose of gentamicin appears to be more efficient in achieving the target serum concentrations than steady state which would be ideal for sepsis, meningitis, and neutropenic fever (Lim et al., 2020).

For neonatal sepsis and Gram-negative and Grampositive infections, they received a dose of $4 \mathrm{mg} / \mathrm{kg}$ of gentamicin as the drug of choice. The trough concentration should not 


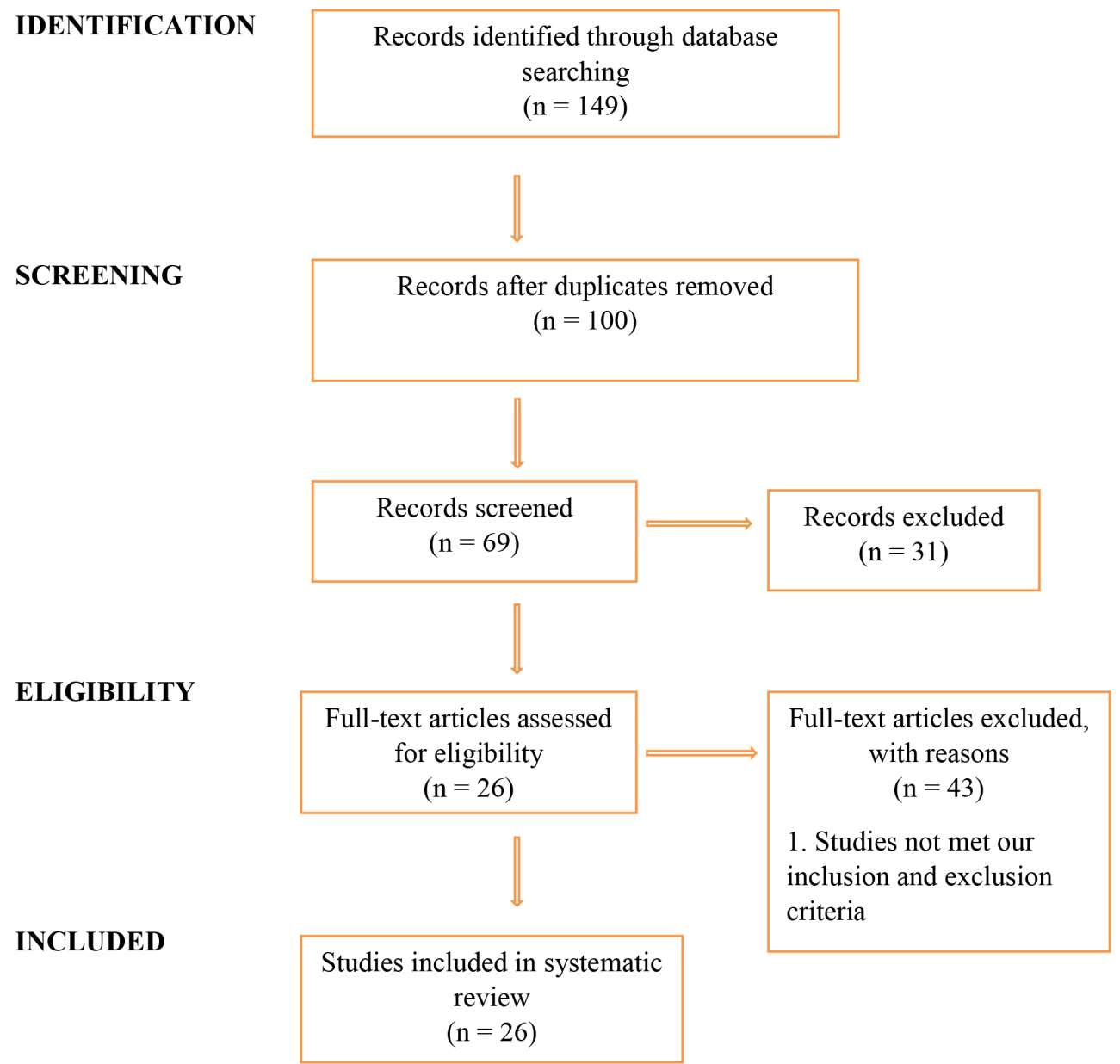

Figure 1. PRISMA flow diagram.

exceed more than $2 \mathrm{mg} / \mathrm{l}$ which can lead to toxicity. A dose 4 $\mathrm{mg} / \mathrm{kg}$ of gentamicin was found to be sufficient to achieve a $C_{\max }$ concentration of $5 \mathrm{mg} / \mathrm{l}$ with a postnatal age. The dose needs to be increased to $7.5 \mathrm{mg} / \mathrm{kg}$ to achieve target peak concentrations of $>10 \mathrm{mg} / \mathrm{l}$; trough concentration $<2 \mathrm{mg} / \mathrm{l}$ in neonates which were effective against sepsis, Gram-negative, and Gram-positive infections (van Donge et al., 2018).

For sepsis, neonates received a dose of $5 \mathrm{mg} / \mathrm{kg} / \mathrm{day}$ of gentamicin, with a target maximum concentration of $20 \mathrm{mg} / \mathrm{l}$. Low serum levels are achieved with a dosing range of 5-8 mg/ $\mathrm{kg} /$ day. A once-daily dose is expected to induce a high $C_{\max } /$ Minimal Inhibitory Concentration (MIC) level. Micro-organism activity with MICs was as high as $2 \mathrm{mg} / \mathrm{l}$ for gentamicin. A lower maximum concentration is achieved by dividing dose and maximum concentration/minimum inhibitory concentration above $8-10 \mathrm{mg} / \mathrm{l}$ would be difficult to reach, particularly for Multi-drug Resistance (MDR) P. aeruginosa (Mareville et al., 2012).

For hypoxic ischemic encephalopathy with hyperthermia, neonates received a dose of $5 \mathrm{mg} / \mathrm{kg} /$ day of gentamicin every 24 hours. Blood samples were collected and their targeted trough concentration $>2 \mathrm{mg} / \mathrm{l}$ and peak concentration $<6 \mathrm{mg} / \mathrm{l}$ were not obtained among the neonates with 24-hour dosing intervals. At 5 $\mathrm{mg} / \mathrm{kg} /$ day every 36 hours of dosing intervals, the targeted trough concentration $<2 \mathrm{mg} / \mathrm{l}$ was obtained in neonates which would be effective against hypoxic-ischemic encephalopathy (Frymoyer et al., 2013). The pharmacokinetic studies' characteristics included in this review are shown in Table 1.

\section{Wound infection}

Wound infections are common conditions in pediatrics which occur mainly in the skin for which gentamicin sulfate cream is used as the drug of choice. A wound swab was collected to check for susceptibility. The Gram-negative bacteria such as $E$. coli $(48.3 \%)$, Proteus species (74\%), K. pneumonia (36\%), and $P$. aeruginosa $(86 \%)$ show sensitivity toward gentamicin, whereas Gram-positive organism shows resistance against gentamicin (Kibret and Abera, 2011; Mama et al., 2014).

\section{Urinary tract infections}

UTI are the most common bacterial infections in neonates and gentamicin is commonly prescribed for the same. The urine samples were collected to check for sensitivity and the following organism such as E. coli, Klebsiella spp., Proteus mirabilis, and $P$. aeruginosa was identified. Escherichia coli shows a resistance of about 30\%-75\% for amikacin, gentamicin. Klebsiella (50\%), P. mirabilis $(52.2 \%)$, and $P$. aeruginosa $(100 \%)$ are sensitive toward 
gentamicin (Abuhandan et al., 2013; Garoy et al., 2019; Kibret and Abera, 2011; Rezaee and Abdinia, 2015; Wang et al., 2014).

Community-acquired and persistent nosocomial infections commonly occur in neonates in hospital settings. Gentamicin is mainly used to treat community-acquired infections in neonates. The swab samples for pus, urine, and sputum were checked for susceptibility. The organisms identified were P. aeruginosa, K. pneumonia, and S. aureus. Pseudomonas aeruginosa (83.5\%), K. pneumoniae (100\%), and S. aureus $(92.4 \%)$ were sensitive toward gentamicin (Ali et al., 2014; Nwankwo and Nasiru, 2011; Shilpa et al., 2016; Sivanmaliappan and Sevanan, 2011; Yadav et al., 2017).

\section{Typhoid fever}

Typhoid fever commonly occurs in pediatrics and is caused by contaminated food and water. Gentamicin is effective against Salmonella typhi mainly in pediatrics. The blood samples were collected for sensitivity and S. typhi was identified; it is susceptible to Ceftriaxone (100\%), Cefixime, Gentamicin (99.4\%), and Ciprofloxacin (98.6\%) (Ali and Sultana, 2016). Probiotics are live micro-organisms that help to provide immunity and prevent the infections in neonates. The swab and sputum samples were checked for sensitivity. Bacteria such as Lactobacillus acidophilus was identified and it is sensitive against gentamicin (Zhou et al., 2005).

\section{Pneumonia}

Pneumonia is the second most commonly occurring bacterial infection in children and gentamicin is a commonly used drug in pneumonia. The sputum was collected and Gram-negative organisms, E. coli, Klebsiella spp., Enterobacter spp., Serratia marcescens, and Acinetobacter spp. were identified. Escherichia coli (87\%), Klebsiella spp. (93\%), Enterobacter spp. (93.9\%),
S. marcescens (95.8\%), Acinetobacter spp. (41\%) are sensitive toward gentamicin (Sader et al., 2014).

\section{Severe acute malnutrition (SAM)}

SAM is more common in children mainly with pneumonia and UTI conditions. A susceptibility test was carried out with urine and sputum samples. Organisms such as E. coli and nontyphoidal Salmonellae were identified and it shows 100\% sensitivity toward gentamicin (Okomo et al., 2011).

Sepsis

Sepsis is more common in neonates; gentamicin is the drug of choice for sepsis. The blood samples were checked for sensitivity and Gram-positive and Gram-negative organisms were identified. Methicillin-resistant $S$. aureus (MRSA) was sensitive toward gentamicin and Klebsiella and E. coli showed high resistance to Cefotaxime (90.5\%), Gentamicin $(75 \%)$, and Ciprofloxacin (76.2\%) (Mokuolu et al., 2002; Pokhrel et al., 2018).

\section{Community-acquired Gram-negative uropathogen infections}

Escherichia coli and $K$. pneumonia were isolated and showed high sensitivity to Ciprofloxacin (95.3\%), Amikacin (93.9\%), Nalidixic acid (92.2\%), Gentamicin (89.2\%), and Nitrofurantoin (83.8\%) (Mohamed et al., 2012).

The organisms were identified from different diseases and their percentages of sensitivity toward gentamicin are shown in Table 2 and their respective characteristics for pharmacodynamics are shown in Table 3.

\section{Pharmacokinetic-Pharmacodynamic Correlation}

The PK-PD model was developed by using in vitro timekill curve experiments; it is classified into two types: static timekill curve experiments and dynamic time-kill curve experiments.

Table 1. Gentamicin doses concerning the achieved concentration.

\begin{tabular}{|c|c|c|c|}
\hline Source & Disease & Dose & Concentration \\
\hline \multirow[t]{2}{*}{ Ismail et al. (1990) } & Gram-negative bacterial infection & $7.5 \mathrm{mg} / \mathrm{kg} / \mathrm{day}$ & Trough concentration $<2 \mu \mathrm{g} / \mathrm{ml}$ \\
\hline & & & Peak concentration $<10 \mu \mathrm{g} / \mathrm{ml}$ \\
\hline \multirow[t]{2}{*}{ Lim et al. (2020) } & Sepsis and meningitis & $5 \mathrm{mg} / \mathrm{kg} /$ day & Trough concentration $<2 \mathrm{mg} / 1$ \\
\hline & & & Peak concentration $8-10 \mathrm{mg} / 1$ \\
\hline van Donge et al. (2018) & Neonatal sepsis and Gram-negative and positive infection & $4 \mathrm{mg} / \mathrm{kg}$ & $C_{\max } 5 \mathrm{mg} / 1$ \\
\hline Mareville et al. (2012) & Sepsis & $5 \mathrm{mg} / \mathrm{kg} /$ day & Target $C_{\max } 20 \mathrm{mg} / 1$ \\
\hline Frymoyer et al. (2013) & Hypoxic ischemic encephalopathy with hyperthermia & $5 \mathrm{mg} / \mathrm{kg} /$ day & Trough concentration $<2 \mathrm{mg} / 1$ \\
\hline
\end{tabular}

Table 2. Organisms identified from different disease conditions and its percentage of sensitivity towards gentamicin.

\begin{tabular}{|c|c|}
\hline Disease condition & Micro-organism and sensitivity \\
\hline Wound infection & E. coli $(48.3 \%)$, Proteus species $(74 \%)$, K. pneumoniae $(36 \%)$, P. aeruginosa $(86 \%)$. \\
\hline UTI & Klebsiella $(50 \%)$ and $P$. aeruginosa $(100 \%)$ \\
\hline Community-acquired, persistent nosocomial & P. aeruginosa $(83.5 \%)$, K. pneumoniae $(100 \%)$, S. aureus $(92.4 \%)$ \\
\hline Typhoid fever & S. typhi $(99.4 \%)$ \\
\hline UTI, wound and ear infections & E. coli $(79.4 \%)$ \\
\hline Gram-negative organism in Intensive Care Unit (ICU) & E. coli (87\%), Klebsiella spp. (93\%), Enterobacter spp. (93.9\%), S. marcescens (95.8\%), Acinetobacter spp. (41\%). \\
\hline SAM & E. coli $(100 \%)$, non-typhoidal Salmonellae (NTS) $(100 \%)$ \\
\hline Neonatal sepsis & MRSA $(70 \%)$ \\
\hline
\end{tabular}


Table 3. Pharmacodynamic study.

\begin{tabular}{|c|c|c|c|c|}
\hline Source & Study design & Disease & Organism & $\begin{array}{c}\text { Sensitivity or resistance } \\
\text { to gentamicin }\end{array}$ \\
\hline Mama et al. (2014) & Cross-sectional & Wound infection & $\begin{array}{c}\text { E. coli }(48.3 \%), \text { Proteus species }(74 \%), \\
\text { K. pneumoniae }(36 \%), \text { P. aeruginosa } \\
(86 \%)\end{array}$ & Sensitivity \\
\hline Kibret and Abera (2011) & Retrospective & Wound infection, UTI, ear infection & E. coli $(79.6 \%)$ & Sensitivity \\
\hline \multirow[t]{2}{*}{ Rezaee and Abdinia (2015) } & Prospective & UTI & E. $\operatorname{coli}(32 \%)$ & Resistance \\
\hline & & & Klebsiella spp. & Sensitivity \\
\hline Garoy et al. (2019) & Cross-sectional study & Skin and soft tissue infection & MRSA $(77 \%)$ & Sensitivity \\
\hline Abuhandan et al. (2013) & Prospective study & UTI & E. coli, Klebsiella spp. & Sensitivity \\
\hline Wang et al. (2014) & Observational study & General infection & P. Mirabilis $(57.7 \%)$ & Sensitivity \\
\hline Yadav et al. (2017) & Prospective study & Community-acquired infection & P. aeruginosa $(53 \%)$ & Sensitivity \\
\hline \multirow[t]{3}{*}{ Shilpa et al. (2016) } & Observational study & Community and hospital-acquired & K. pneumonia $(37.50 \%)$ & Resistance \\
\hline & & infection & K. pneumonia $(62.50 \%)$ & \\
\hline & & & & Sensitivity \\
\hline Onwubiko et al. (2015) & Prospective study & Nosocomial infection & S. aureus $(63 \%)$ & Sensitivity \\
\hline Sivanmaliappan et al. (2011) & Prospective study & Soft tissue infection & P. aeruginosa $(66.6 \%)$ & Resistance \\
\hline Ali et al. (2014) & Observational study & $\begin{array}{l}\text { Community-acquired infection } \\
\text { Gram-negative uropathogens }\end{array}$ & E. coli and K. pneumonia $(89 \%)$ & Sensitivity \\
\hline Ali et al. (2014) & Prospective study & Typhoid fever & S. typhi $(99.4 \%)$ & Sensitivity \\
\hline Zhou et al. (2005) & Observational study & New probiotics & L. acidophilus & Sensitivity \\
\hline \multirow[t]{6}{*}{ Sader et al. (2014) } & Retrospective study & Gram-negative infections & P. aeruginosa $(87 \%)$ & Sensitivity \\
\hline & & & Klebsiella spp. (91\%) & \\
\hline & & & E. $\operatorname{coli}(84.2 \%)$ & \\
\hline & & & Enterobacter spp. (94.8\%) & \\
\hline & & & Acinetobacter spp. $(29.5 \%)$ & \\
\hline & & & Serratia spp. (97.7\%) & \\
\hline Okomo et al. (2011) & Retrospective study & SAM & E. coli $(100 \%)$, NTS $(100 \%)$ & Sensitivity \\
\hline Pokhrel et al. (2018) & $\begin{array}{l}\text { Retrospective cross- } \\
\text { sectional study }\end{array}$ & Neonatal sepsis & Klebsiella $(75.5 \%)$ & Resistance \\
\hline Mokuolu et al. (2002) & Retrospective study & Sepsis & S. aureus $(62.5 \%)$ & Sensitivity \\
\hline
\end{tabular}

The correlation was carried out by the semi-mechanistic PK-PD model which describes the time course of the drug concentration and the bacterial growth and killing after antibacterial treatment. For an extremely preterm new-born infant, the highest possible dose is $6 \mathrm{mg} / \mathrm{kg}$ for a 36-hour interval, while a dose of $7 \mathrm{mg} / \mathrm{kg}$ with a 36-hour interval in the typical term newborn infant. Dosing intervals should longer than 24 hours for extremely preterm infants to reach trough levels of $<2 \mathrm{mg} / 1$, unless the dose is reduced to less than $4 \mathrm{mg} / \mathrm{kg}$. To achieve concentrations of $<1 \mathrm{mg} / \mathrm{l}$ in typical newborn infants, doses of 4 and $5 \mathrm{mg} / \mathrm{kg}$ with a 36 -hour interval is recommended (Carapetis et al., 2001; Nielsen et al., 2011).

In sepsis conditions, $5 \mathrm{mg} / \mathrm{kg} /$ day of gentamicin shows a minimum inhibitory concentration of $>2 \mathrm{mg} / \mathrm{l}$ toward $E$. coli, P. aeruginosa, Staphylococcus epidermidis, Enterobacter spp., Streptococci, S. aureus, K. pneumoniae, and Citrobacter diversus. For MDR $P$. aeruginosa, the minimum inhibitory concentration in the range of $8-10 \mathrm{mg} / \mathrm{l}$ is not shown (Frymoyer et al., 2013).

In urinary tract infection, 4.5-7.5 $\mathrm{mg} / \mathrm{kg} / \mathrm{day}$ of gentamicin shows minimum inhibitory concentration $>2 \mathrm{mg} / \mathrm{l}$ toward Gram-negative bacilli, Enterococci, and Staphylococcus spp. (Carapetis et al., 2001). In severe malnutrition, $7.5 \mathrm{mg} / \mathrm{kg} /$ day of gentamicin shows a minimum inhibitory concentration of
$>2 \mathrm{mg} / \mathrm{l}$ toward Plasmodium falciparum and E. coli (Seaton et al., 2007).

\section{CONCLUSION}

This review focuses on gentamicin correlating the pharmacokinetics and pharmacodynamics data by using the semimechanistic PK-PD model. This review guides us about how to correlate the pharmacokinetic and pharmacodynamic data. It will help us find out at what concentration gentamicin shows resistance and sensitivity toward bacteria, especially in pediatric population.

\section{ACKNOWLEDGMENT}

The authors would like to thank the staff of the Department of Pharmacy Practice, JSS College of Pharmacy, Ooty, for their support.

\section{AUTHORS' CONTRIBUTION}

Keerthana Chandrasekar and K. P. Arun formulated the hypothesis. B. Vahini, V. Vijay, and R. Shalini carried out the data collection and analysis. All the authors read and accepted the final manuscript. 


\section{CONFLICT OF INTEREST}

The authors declare no conflict of interest.

\section{FUNDING}

None.

\section{ETHICAL APPROVAL}

Not applicable.

\section{REFERENCES}

Abuhandan M, Güzel B, Oymak Y, Çiftçi H. Antibiotic sensitivity and resistance in children with urinary tract infection in Sanliurfa. Turk $\mathrm{J}$ Urol, 2013; 39(2):106-10.

Ali A, Tayebah V, Farid K, Tayebah A, Farhad A, Marziaeh A. Antimicrobial susceptibility patterns of community-acquired Gramnegative uropathogens. Afr J Microbiol Res, 2014; 8:332-6.

Ali MK, Sultana S. Antimicrobial sensitivity patterns of Salmonella typhi in children. Bangladesh J Med Sci, 2016; 15(3):416-8.

Bloomfield SE, Miyata T, Dunn MW, Bueser N, Stenzel KH, Rubin AL. Soluble gentamicin ophthalmic inserts as a drug delivery system. Arch Ophthalmol, 1978; 96(5):885-7.

Carapetis JR, Jaquiery AL, Buttery JP, Starr M, Cranswick NE, Kohn S, Hogg GG, Woods S, Grimwood K. Randomized, controlled trial comparing once daily and three times daily gentamicin in children with urinary tract infections. Pediatr Infect Dis J, 2001; 20(3):240-6.

Frymoyer A, Meng L, Bonifacio SL, Verotta D, Guglielmo BJ. Gentamicin pharmacokinetics and dosing in neonates with hypoxic ischemic encephalopathy receiving hypothermia. Pharmacotherapy, 2013; 33(7):718-26.

Garoy EY, Gebreab YB, Achila OO, Tekeste DG, Kesete R, Ghirmay R, Kiflay R, Tesfu T. Methicillin-resistant Staphylococcus aureus (MRSA): prevalence and antimicrobial sensitivity pattern among patients-a multicenter study in Asmara, Eritrea. Can J Infect Dis Med Microbiol, 2019; 2019:8321834

Garraghan F, Fallon R. Gentamicin: dose regimens and monitoring. Pharm J, 2015; 295(7874):1-11.

Graham DR, Dixon RE, Hughes JM, Thornsberry C. Disk diffusion antimicrobial susceptibility testing for clinical and epidemiologic purposes. Am J Infect Control, 1985; 13(6):241-9.

Haddad NS, Ravis WR, Pedersoli WM, Carson RL Jr. Pharmacokinetics of single doses of gentamicin given by intravenous and intramuscular routes to lactating cows. Am J Vet Res, 1986; 47(4):808-13.

Hahn FE, Sarre SG. Mechanism of action of gentamicin. J Infect Dis, $1969 ; 119(4): 364-9$

Ismail R, Sarriff A, Abdul Rahman AF. Therapeutic drug monitoring for gentamicin in Hospital Universiti Sains Malaysia. Med J Malays, 1990; 45(1):57-64.

Khan ZA, Siddiqui MF, Park S. Current and emerging methods of antibiotic susceptibility testing. Diagnostics (Basel), 2019; 9(2):49.

Kibret M, Abera B. Antimicrobial susceptibility patterns of E. coli from clinical sources in northeast Ethiopia. Afr Health Sci, 2011; 11(Suppl 1):S40-5.

Krause KM, Serio AW, Kane TR, Connolly LE. Aminoglycosides: an overview. Cold Spring Harb Perspect Med, 2016; 6(6):a027029.

Kushner B, Allen PD, Crane BT. Frequency and demographics of gentamicin use. Otol Neurotol, 2016; 37(2):190-5.

Lim WXS, Chua WBB, Chua JM, Lee Q, Chan JW, Sultana R, Poh BH. A retrospective review of the efficiency of first-dose therapeutic drug monitoring of gentamicin, amikacin, and vancomycin in the pediatric population. J Clin Pharmacol, 2020; 60(1):7-15.

Lundergan FS, Glasscock GF, Kim EH, Cohen RS. Once-daily gentamicin dosing in newborn infants. Pediatrics, 1999; 103(6 Pt 1):1228-34.

MacDougall C, Chambers HF. Aminoglycosides. In: Brunton LL, Chabner BA, Knollman BJ, (eds.). Goodman \& Gilman's the pharmacological basis of therapeutics, 12th edition, McGraw-Hill, New York, NY, pp 1505-20, 2011.

Mama M, Abdissa A, Sewunet T. Antimicrobial susceptibility pattern of bacterial isolates from wound infection and their sensitivity to alternative topical agents at Jimma University Specialized Hospital, SouthWest Ethiopia. Ann Clin Microbiol Antimicrob, 2014; 13:14.

Mareville J, Gay J, Cliquennois E, Herbaux C, Pasquier F, Allorge D, Blondiaux N, Berthon C, Alfandari S. Therapeutic drug monitoring of aminoglycosides in acute myeloid leukaemia patients. Scand J Infect Dis, 2012; 44(5):398-401.

Meibohm B, Derendorf H. Basic concepts of pharmacokinetic/ pharmacodynamic (PK/PD) modelling. Int J Clin Pharmacol Ther, 1997; 35(10):401-13.

Mohamed AF, Nielsen EI, Cars O, Friberg LE. Pharmacokineticpharmacodynamic model for gentamicin and its adaptive resistance with predictions of dosing schedules in newborn infants. Antimicrob Agents Chemother, 2012; 56(1):179-88.

Mokuolu AO, Jiya N, Adesiyun OO. Neonatal septicaemia in Ilorin: bacterial pathogens and antibiotic sensitivity pattern. Afr J Med Med Sci, 2002; 31(2):127-30.

Nielsen EI, Cars O, Friberg LE. Pharmacokinetic/ pharmacodynamic (PK/PD) indices of antibiotics predicted by a semimechanistic PKPD model: a step toward model-based dose optimization. Antimicrob Agents Chemother, 2011; 55(10):4619-30.

Nocton JJ, Gedeit R. Aminoglycosides. Gentamicin pharmacokinetics. 4th edition, Elsevier Health Sciences, Philadelphia, PA, pp 287-302, 2018 .

Noone P, Pattison JR. Therapeutic implications of interaction of gentamicin and penicillins. Lancet, 1971; 2(7724):575-8

Nwankwo EO, Nasiru MS. Antibiotic sensitivity pattern of Staphylococcus aureus from clinical isolates in a tertiary health institution in Kano, Northwestern Nigeria. Pan Afr Med J, 2011; 8:4.

Okomo UA, Garba D, Fombah AE, Secka O, Ikumapayi UN, Udo JJ, Ota MO. Bacterial isolates and antibiotic sensitivity among Gambian children with severe acute malnutrition. Int J Pediatr, 2011; 2011:825123.

Onwubiko NE and Akande AO. Microbial Contamination In The Operating Theatre Of a Tertiary Health Institution In Kano, Northwestern Nigeria. Nigerian Journal of Microbiology 2015; 27(1):2671-79

Pacifici GM. Clinical pharmacology of gentamicin in neonates: regimen, toxicology and pharmacokinetics. MedicalExpress, 2015; 2(5):M150501

Pokhrel B, Koirala T, Shah G, Joshi S, Baral P. Bacteriological profile and antibiotic susceptibility of neonatal sepsis in neonatal intensive care unit of a tertiary hospital in Nepal. BMC Pediatr, 2018; 18(1):208.

Rezaee MA, Abdinia B. Etiology and antimicrobial susceptibility pattern of pathogenic bacteria in children subjected to UTI: a referra hospital-based study in Northwest of Iran. Medicine (Baltimore), 2015; 94(39):e1606.

Sader HS, Farrell DJ, Flamm RK, Jones RN. Antimicrobial susceptibility of Gram-negative organisms isolated from patients hospitalized in intensive care units in United States and European hospitals (2009-2011). Diagn Microbiol Infect Dis, 2014; 78(4):443-8.

Saleh P, Abbasalizadeh S, Rezaeian S, Naghavi-Behzad M, Piri R, Pourfeizi HH. Gentamicin-mediated ototoxicity and nephrotoxicity: a clinical trial study. Niger Med J, 2016; 57(6):347-352.

Seaton C, Ignas J, Muchohi S, Kokwaro G, Maitland K, Thomson AH. Population pharmacokinetics of a single daily intramuscular dose of gentamicin in children with severe malnutrition. J Antimicrob Chemother, 2007; 59(4):681-9.

Shilpa K, Thomas R, Ramyashree A. Isolation and Antimicrobial sensitivity pattern of Klebsiella pneumoniae from sputum samples in a tertiary care hospital. Int J Biomed, 2016; 7(2):53-7.

Sivanmaliappan TS, Sevanan M. Antimicrobial susceptibility patterns of Pseudomonas aeruginosa from diabetes patients with foot ulcers. Int J Microbiol, 2011; 2011:605195. 
Taylor M, Keane C. Gentamicin dosage in children. Arch Dis Child, 1976; 51(5):369-72.

Tozer TN, Rowland M. Introduction to pharmacokinetics and pharmacodynamics: the quantitative basis of drug therapy. Lippincott Williams \& Wilkins, Philadelphia, PA, pp 1-13, 2006.

van Donge T, Pfister M, Bielicki J, Csajka C, Rodieux F, van den Anker J, Fuchs A. Quantitative analysis of gentamicin exposure in neonates and infants calls into question its current dosing recommendations. Antimicrob Agents Chemother, 2018; 62(4):e02004-17.

Wang JT, Chen PC, Chang SC, Shiau YR, Wang HY, Lai JF, Huang IW, Tan MC, Lauderdale TL; TSAR Hospitals. Antimicrobial susceptibilities of Proteus mirabilis: a longitudinal nationwide study from the Taiwan surveillance of antimicrobial resistance (TSAR) program. BMC Infect Dis, 2014; 14:486.

Yadav VC, Kiran VR, Jaiswal MK, Singh K. A study of antibiotic sensitivity pattern of Pseudomonas aeruginosa isolated from a tertiary care hospital in South Chhattisgarh. Int J Med Sci Public Health, 2017; 6(3):600-5.

Zhou JS, Pillidge CJ, Gopal PK, Gill HS. Antibiotic susceptibility profiles of new probiotic Lactobacillus and Bifidobacterium strains. Int $\mathbf{J}$ Food Microbiol, 2005; 98(2):211-7.

How to cite this article:

Chandrasekar K, Vahini B, Vijay V, Shalini R, Arun KP. Gentamicin pharmacokinetics and pharmacodynamic correlation in pediatrics - A systematic review. J Appl Pharm Sci, 2021; 11(11):011-017. 